\title{
Destination Loyalty and preference to Oman: Examining the Influences of Tourists' Demographics
}

\section{Mohamed Ali Ahmed Obaid, PhD}

\author{
Tourism Studies Department, Faculty of Tourism and Hotels
}

Fayoum University, Egypt

\begin{abstract}
The aim of this study was threefold: 1) to investigate the tourists' loyalty and preference towards Oman tourism destination; 2) to assess the impact of destination preference on destination loyalty; and 3) to examine the potential differences in tourists' loyalty and preference across different demographic groups. A self-administered questionnaire was developed and a sample of 300 inbound tourists in Oman was targeted. The descriptive analysis findings revealed that inbound tourists have high loyalty to Omani tourism destination through appearing high revisit intentions and high recommend intentions. In addition, Oman tourism destination is highly preferred by inbound tourists. The findings of regression analysis argued that destination preference has a positive and significant impact on destination loyalty. The findings of ANOVA analysis and Independent Samples T-Test concluded that tourists' demographics (gender, age, marital status and education) have no significant influences over their perceptions towards both destination loyalty and preference. The theoretical and managerial implications were drawn based on the study findings and recommendations for future researchers were presented.
\end{abstract}

Keywords: Tourism, Destination Loyalty, Destination Preference, Demographic Characteristics

\section{Introduction}

Due to the increasingly importance of loyalty aroused in the marketing literature as well as the tourism literature, customer loyalty is often taunted as something to be desired in the tourism and hospitality organizations. ${ }^{12} 3$ Customer loyalty is viewed as one of the most critical driving forces of business success due to every aspect of a business system is significantly influenced by the level and degree of customer loyalty. ${ }^{4}$ The most popular definition of loyalty is that of Oliver ${ }^{5}$, whereby loyalty is " a deeply held commitment to re-buy or re-patronize a preferred product/service consistently in the future, thereby causing repetitive same-brand or same brand set purchasing, despite situational influences and marketing efforts having the potential to cause switching behavior"'(p. 34). In the field of tourism destination, destination loyalty defined as "the level of tourists' perceptions of a destination as a recommendable place" (p. 39). ${ }^{6}$ The tourism literature stresses the importance of building a loyal customer as the foundation of product or organization or destination success. ${ }^{789}$ Developing loyal customers has been shown to result in a number of positive benefits, such as reducing the amount of investment in marketing efforts to solicit new customers, enhancing customer acquisition, improving customer retention, and increasing brand equity and profit. ${ }^{9}$ It is believed that a $5 \%$ enhancement in customer retention can increase the profitability in the range of 25 to $85 \%$, depending on the industry sector. ${ }^{10}$ Schiffman and Kanuk ${ }^{11}$ also claimed that it is more expensive to win new customers compared to keeping existing customers.

In an era of budget constraints and increased competition among tourism service providers, loyal customers are alleged to be less sensitive to higher or increased pricing. ${ }^{8}$ loyal customers spend more with the service providers in the short term ${ }^{12}$. In the long term, loyal customers attract new customers by word of mouth ${ }^{7}{ }^{13}$. Moreover, loyalty offers greater opportunities to recover the customer in the event of errors or service deficiencies. According to Weiner ${ }^{14}$, loyal customers usually attribute errors to unstable factors or factors over which the supplier has little control. Therefore, destination marketers as well as managers of tourism-based organizations need to understand and be concerned about tourists' loyalty and preference toward a tourism destination that result from their experiences.

Prior research studied the effects of different demographic variables on satisfaction and loyalty. ${ }^{15}$ Exter $^{16}$ found that people's loyalty towards a brand did not vary based on their demographic background. Other researchers found that age may have influence on consumer loyalty and older customers tended to be more satisfied and loyal than younger ones. ${ }^{11} 17$ Mykletun, Crotts, and Mykletun ${ }^{18}$ studied the relationship between a number of demographic variables including age, household income, and education versus visitors' perception of a destination and revisit probability. They found that (a) none of the demographic variables (age, education, and income) was significantly related to visitors' revisit probability and (b) only age was an important predictor of visitor satisfaction-senior tourists ( $\geq 60$ years old) held the most positive evaluations of a destination compared with the younger visitor segment; no other demographic variables (income or education) had any significant effect on visitor satisfaction. Therefore, destination marketers need to develop a better 
understanding of the specific groups of consumers in order to accommodate their requirements, and identify consumers with similar needs or characteristics.

The current study investigated whether tourists' loyalty and preference are high or low, and whether their demographics affect their perceptions towards loyalty and preference of Oman tourism destination. More specifically, this study was undertaken to (a) explore the tourists' perceptions of destination loyalty and preference towards Oman tourism destination; (b) assess the relationship between destination preference and destination loyalty; and c) examine the influence of tourists' demographic characteristics on both tourists' loyalty and preference towards Oman tourism destination. The findings could help Omanis destination marketers in understanding tourists' loyalty and preference toward Oman tourism destination. The findings could also aid destination managers in carrying out market segmentation. Moreover, the findings would contribute to advances in the theoretical understanding of the effects of demographic variables on the destination loyalty and preference.

\section{Destination loyalty}

Although loyalty is a relatively recent discipline, the deficiencies of measuring loyalty - by behavior or attitudes - have been questioned since the $1960 \mathrm{~s} .{ }^{19}$ Research into brand loyalty and/or consumer loyalty was dated back well more than 40 years. According to Jacoby and Chestnut ${ }^{20}$, its history extended back to Copeland's study on a phenomenon that he labeled "brand insistence." In the wider area of tourism, hospitality, recreation, and leisure, loyalty research is a much more recent phenomenon, dating back around 20 years. $^{21}$ Jacoby and Chestnut $^{20}$ noted that two important assumptions about brand loyalty measurement are generally made. The first concerns the level at which brand loyalty is measured (micro or individual level vs. macro or aggregate level). The second assumption concerns the data used to measure brand loyalty. They distinguished three approaches to data usage: behavioral data, attitudinal data, and composite (combination of both).

The behavioral approach represents the earliest approach to loyalty measurement ${ }^{7}$ that focuses on tourist's consumption behavior. ${ }^{22}$ It is based on measuring brand purchase sequence, brand purchase proportion, or probability of purchase. $^{20}$ This approach has been criticized for its lack of clarity with respect to its conceptual framework and inability to explain the factors that influence customer loyalty. ${ }^{23}$ However, the behavior approach was criticized for its inability to distinguish between intentional/latent loyalty and spurious loyalty. Intentional/latent loyal customers are those who despite having a strong attitudinal attachment to the services or products, they exhibit low usage. Patronage barriers (such as price, convenience, or location) may cause these customers to share their purchase behavior with multiple service alternatives. Spurious loyal customers are those who exhibit a high level of behavioral patronage yet have a weak sense of attitude attachment. Such customers are more likely to switch services if better alternatives become available, as their patronage tends to be price sensitive. ${ }^{71923}$

The attitudinal perspective refers to tourist's attitude toward a destination or a tourism product. ${ }^{122}$ This approach has been criticized as well, given that neither the data collected on attitudinal measures are convincing ${ }^{20}$ nor the survey instruments used to collect such data are psychometrically sound. ${ }^{24}$ The composite approach is an integration of behavioral and attitudinal measures. ${ }^{23}$ This composite approach is believed to be the most comprehensive approach, but it also has limitations simply because of the weighting applied to both behavior and attitudinal components as well as to the various components within each of those. ${ }^{7}$ Moreover, the composite approach involves several risks such as improper multiplication of attitudinal and behavioral attributes, selection of inadequate items, neglect of the impacts of significant intervening variables, and lack of underlying theoretical supports. ${ }^{1}$

The measurement of loyalty in a tourism context is particularly difficult, since the purchase of a tourism product is a rare purchase. ${ }^{25}$ It does not occur on a continuous basis but rather infrequently. ${ }^{26}$ It can also be covert behavior as reflected in intention to revisit in the future. ${ }^{27}$ Furthermore, frequent patronage may not be a true indicator of loyalty because the loyalty that hospitality operators seek involves attitudinal and emotional commitment to their brands. ${ }^{28}$ Because a tourist product differs from a manufactured product, repeat purchase behavior might not truly reflect a tourist's loyalty to a tourist product. It may be true that loyal tourists are more inclined to use the same airline and stay in the same franchised hotel wherever they travel; however, the tenet may not be necessarily applied to the selection of travel destination. ${ }^{6}$

Moreover, according to the review of destination loyalty measurements by Velázquez, Saura and Molina ${ }^{29}$, despite the multidimensional measurements of loyalty and consensus in the literature over conceptualizing it on the basis of behavior and attitude or intention, many studies only use the attitudinal component and there are fewer studies which use only purchase behavior as loyalty indicator. Hence, in this study, destination loyalty is referred to as tourists' intentions to revisit and their recommendations to others. ${ }^{723}$

Regarding the typology of destination loyalty, the work of Backman ${ }^{30}$ is considered as the first work of loyalty typologies. He identified four levels of loyalty in relation to the psychological component (effective assessment of the experience) and the behavioral component: low loyalty, latent loyalty, false loyalty and high loyalty. Subsequent studies in 
the area of tourism have used this measurement tool. ${ }^{1}{ }^{31}$ However; Opperman ${ }^{32}$ criticized the simplicity of Backman's proposal and continuing with the double component. He proposed a measurement of loyalty which distinguished between first visit tourists and repeat tourists. This procedure was subsequently used by Petrick ${ }^{33}$ who identified six categories of loyal customers in relation to the number of experiences and their evaluation: disappointed, possibly loyal, not very loyal, false loyal, latent loyal and very loyal. On these same lines the work by Rundle-Thiele ${ }^{34}$ concludes that consumers have different states or degrees of loyalty, identifying six loyalty dimensions in services: attitudinal loyalty, resistance to the competition's offer, behavioral intentions, propensity to loyalty, complaint behavior and behavioral loyalty.

A tentative destination loyalty typology was developed by Oppermann ${ }^{25}$ identifying seven types of destination loyalty: non-purchasers, disillusioned, unstable, disloyal, somewhat loyal, loyal, and very loyal. The non-purchasers are potential customers who have never visited the destination in their whole life. The disillusioned segment consists of previous one-time visitors who did not have a satisfactory experience and for that reason will never return to the destination. The unstable people are always visiting a different destination in a constant desire for novelty and new experiences; even when they have a very positive experience they will not return to the destination. The disloyal travelers are characterized by a lesser quest for the novel and, in contrast to the unstable travelers, may return in future to the destination. The last three categories are differentiated by frequency and intensity of previous visits rather than by their attitudes or beliefs. The very loyal traveler is returning to the destination every year or perhaps every second year. The loyal travelers are those who visit the destination regularly but not every year. Perhaps visiting the destination every third or fourth year, this traveler appreciated the destination but also wants to experience other places. The somewhat loyal category includes travelers who have visited the destination at least twice before but hardly more than that. They obviously were re-attracted to the destination but that has not translated into regular visitation behavior.

The more nuanced understanding that emerges from such syntheses is illustrated by Backman and Crompton ${ }^{35}$, who predictably distinguish between high loyalty resulting from repeat patronage and positive attitudes and low loyalty, indicating non-repeat behavior and a lack of positive attitudes. Therefore, the followings hypothesis was designed:

\section{H1: Inbound tourists have high loyalty to Omani tourism destination.}

\section{Destination Preference}

Destination preference is defined as the extent to which the tourist favors a certain type of destination in comparison to other destinations. It was seen as direct antecedent of destination choice. Preference has also been used as a measure of loyalty. It is a psychological commitment and favorable attitude towards a place, which often led to repeated patronage and word-of-mouth. ${ }^{36}$ Hedlund $^{36}$ indicated that many different choice theories have emerged from the mid-1900s and to present date, trying to explain how individuals make choices and which factors that influence the decision making process, e.g. the expected utility theory, prospect theory, regret theory, satisfying theory, the theory of reasoned action, and theory of planned behavior.

Three types of tourism choice models have emerged in the literature; microeconomic models, cognitive models, and interpretive models. ${ }^{37}$ Microeconomic models try to explain tourism behavior by using traditional demand models with a normative focus on how the consumer should behave. Cognitive choice models focus on socio-psychological variables and processes involved in making choices ${ }^{37}$ and a distinction can be made between structural and process approaches. ${ }^{38}$ Structural models, i.e. choice-set models, focus on the relation between input (available information about alternatives) and output (choice between alternatives). Making a choice involves an evaluation and selection where different destinations in the consideration set are compared on an attribute or alternative basis. The use of structural models can help researchers to understand how tourists reach a final choice in one specific sub-choice and how the trade-off is made within this sub-choice.

An important criticism of structural and process models is that they fail to recognize the inter-relationship between vacation choices. ${ }^{39} 40$ This gap in tourism choice models is filled to some extent by the interpretive models. These models take the choice context into account and also recognize that many different components and processes are involved in tourism choices. ${ }^{41}{ }^{42}$ They also take new variables and hypotheses into account which were not included in the traditional models. Interpretive models take the personal, social, and cultural context into account and leave the deterministic approach presented by earlier models. ${ }^{37}$ In spite of the significant contributions from studies on choice behaviors, literature that is pertaining to the relationship between destination preference and tourists' destination loyalty is rather limited. ${ }^{36}$ Therefore, to what extend destination preference affects loyalty of tourists in a favorable way requires further investigation. The investigation is deemed to be important since a proven close relationship of destination preference and loyalty could reform the marketing goals of tourism destinations in the future. Therefore, the study proposed and tested the hypotheses below:

\section{H2: Oman tourism destination is highly preferred by inbound tourists.}

\section{H3: Destination preference has direct positive and significant effects on destination loyalty.}




\section{The Influences of Demographic Characteristics on Destination Loyalty and Preference}

Because of rapidly changing demographics of the travel market, demographics based research has drawn increasing attention in the tourism and travel literature. A number of studies have been conducted to investigate the effects of tourist demographics on their loyalty perceptions and destination preference; mixed results were generated from these studies. ${ }^{15}$ Age-based research has received increasing attention in the tourism literature and mixed findings were concluded. Lepsito and McCleary's empirical study concluded that age did not affect customer preference for a particular type of hotel for pleasure travel. ${ }^{43}$ Examination of park preferences revealed that older adults were more likely to prefer recreation to conservation than younger adults. ${ }^{44}$ Also, Dimitriades ${ }^{45}$ found no significant relationship between age and loyalty in tourism services. Recently, the findings of $\mathrm{Chi}^{3}$ revealed that travelers in different age segments exhibited no significant difference in their perception of the destination loyalty.

However, others argued that a traveler's age was likely to significantly influence his or her post-visit behavior. For example, Moisey and Bichis ${ }^{46}$ reported that seniors and non-seniors were different in their travel motivation, visitation patterns, and recreation activities. Older customers (age $\geq 50$ years) tended to show higher satisfaction and loyalty than the younger group (age $<50$ years). ${ }^{17}$ Others revealed contrary findings, for example, Wood ${ }^{47}$ suggested that older consumers have less behavior change intention. According to Patterson ${ }^{48}$, younger consumers and housewives are more loyal to travel agencies, older consumers and retired show higher repurchase intentions. Hossain ${ }^{49}$ argued that visitors in different age and education segments had different levels of perceptions about service of the destination: younger visitors held more positive perceptions than did senior visitors.

Gender-based research has also inspired growing interests in the tourism literature. For example, CrawfordWelch ${ }^{50}$ observed that female and male business travelers had similar consumption patterns. The findings of $\mathrm{Chi}^{3}$ shared the same and found comparable levels of loyalty and preference across males and females. However, McCleary, Weaver, and $\operatorname{Lan}^{51}$ investigated whether male and female business travelers employed different criteria for hotel selection and service use. They found that the two gender groups differed only at some selected attribute levels. Meng and Uysal ${ }^{52}$ found that when tourists consider destinations, significant gender differences existed regarding the perceived importance of destination attributes and travel values. While McColl-Kennedy, Daus, and Sparks ${ }^{53}$ argued that Women show higher levels of loyalty in services than men, women feel greater affect towards the supplier ${ }^{30} 33$, and male tend to be more attitudinally and behaviorally loyal. ${ }^{54}$

Although marital status has a rare show, education appeared to receive intentions in the tourism literature. While some studies showed no influence for education on loyalty and preference ${ }^{3}$, others argued that higher educated visitors have more influence on destination operators than lower level of education. ${ }^{49}$ Based on the debate raised above, the following hypothesis was designated:

H4: Demographics (gender, age, marital status and education) have no influence on tourists' loyalty and preference.

\section{Research methods}

\section{Measurement}

Due to the study's objectives, this research is considered as exploratory research as well as causal-effect research. As a large sample of inbound tourists was surveyed using a rating scale, quantitative approach was adopted in this study to achieve objectives and test hypotheses. The operational definition for destination loyalty that is adopted in the current study perceive it as tourists' intention to revisit and their recommendations to others. In other words, attitudinal approach was adopted to measure tourists' perception towards destination loyalty. The loyalty typology proposed by Backman and Crompton ${ }^{35}$ is used in results interpretation to distinguish between high loyalty resulting from positive attitudes and low loyalty resulting from a lack of positive attitudes.

The loyalty scale developed by Zeithaml et al. ${ }^{22}$ has been modified to measure destination loyalty in this study. The original scale exhibited a high reliability with Cronbach's alpha equaling to 0.9. The original scale of Zeithaml and his colleagues includes five attributes as follows: 1) Say positive things about the company; 2) Recommend Company; 3) Remain loyal to company; 4) Spend more with company; and 5) Pay price premium. In this study, the scale used to measure the destination loyalty was composed of eight items including: 1) I will recommend Oman to others (including my family and friends); 2) I will say positive things about Oman to other people; 3) I will encourage other people to visit Oman; 4) I will consider Oman again while travelling abroad for a holiday; 5) I will visit Oman again within the next 2 Years; 6) I would like to stay longer in Oman if I could; 7) There are many other attractions that I want to visit in Oman; and 8) I don't think that I spent enough time in Oman. Because of the nature of destination loyalty, the final result is likely to be either unidimensional or two-dimensional. The possible dimensions of the destination loyalty scale are tourist intentions to revisit 
the destination (revisit intentions) and recommend the destination to others (recommendation intentions). Destination loyalty are measured with a 7-point Likert scale ranging from 1: totally disagree to 7: totally agree.

Based on the measurement of brand preference ${ }^{55}$, four items were designed to measure destination preference, two of which are reversed scale for negative expressions. The four attributes used to measure destination preference are: 1) Oman is my first choice; 2) Oman is more attractive to me than any other foreign destinations; 3) I am more interested in visiting other destinations than Oman; and 4) I intend to visit other destination than Oman in the near future. A 7-point Likert scale (ranging from 1: totally disagree to 7: totally agree) was used to measure destination preference in this study.

\section{Data Collection and analysis}

The data sets used in this study were collected using a self-administrated questionnaire. The questionnaire was developed based upon items contribution from the literature. A random sample of 300 international tourists in Oman was targeted during the period of September 2013 to December 2013 with the assistance of travel agents and hotels in Muscat and Dhofar governorates. Each tourist was asked to rate his/her perception relating to the two constructs understudy using a 7 point Likert scale. The questions about respondents' demographic profile concerned with: Gender, age, marital status, and education.

A progressive series of statistical analyses were carried out using SPSS version 19. First, a pilot test was conducted to validate the research's constructs and model. Convergent validity test and discriminant validity test were used to verify validity. Cronbach's alpha test was used for checking reliability. Second, a descriptive analysis was used to examine the profile of the respondents, test the normality of data distribution, and describe the nature and level of destination loyalty and preference. Independent samples T-Test and ANOVA Test were used to examine the influence of tourists' demographic characteristics on both destination loyalty and preference.

\section{Pilot Test}

The questionnaire was pre-tested using a random sample of 200 foreign and domestic tourists in Oman (80\% response rate) to assess the operationalization feasibility of the survey approach. Male respondents accounted for $75.6 \%$ of total respondents and female accounted for $24.4 \%$ of total respondents. The majority of the respondents (81.9\%) were married. Majority of respondents received tertiary education at undergraduate level $(57.5 \%)$ or higher $(11.9 \%)$. Regarding traveler type, foreign tourists accounted for $42.5 \%$ and domestic tourists accounted for $57.5 \%$.

Table 1: Convergent validity and reliability tests for destination loyalty and preference scales $(n=160)$

\begin{tabular}{llcc}
\hline Construct/Item & $\begin{array}{c}\text { Item-Total } \\
\text { Correlation }\end{array}$ & $\begin{array}{c}\text { Cronbach's } \\
\text { Alpha if item } \\
\text { deleted }\end{array}$ & $\begin{array}{c}\text { Reliability } \\
\text { Coefficient }\end{array}$ \\
\hline DL & DESTINATION LOYALTY & & $\mathbf{. 8 0 2}$ \\
DL1 & I will recommend Oman to others (including my family and & $.545^{* *}$ & 0.798 \\
& friends). & $.685^{* *}$ & 0.772 \\
DL2 & I will say positive things about Oman to other people. & $.701^{* *}$ & 0.771 \\
DL3 & I will encourage other people to visit Oman. & $.691^{* *}$ & 0.772 \\
DL4 & I will consider Oman again while travelling abroad for a holiday. & $.585^{* *}$ & 0.791 \\
DL5 & I will visit Oman again within the next 2 Years. & $.760^{* *}$ & 0.758 \\
DL6 & I would like to stay longer in Oman if I could. & $.588^{* *}$ & 0.791 \\
DL7 & There are many other attractions that I want to visit in Oman. & $.620^{* *}$ & 0.786 \\
DL8 & I don't think that I spent enough time in Oman. & & \\
& & & \\
DP & DESTINATION PREFERENCE & $.697^{* *}$ & 0.731 \\
DP1 & Oman is my first choice. & $.710^{* *}$ & 0.701 \\
DP2 & Oman is more attractive to me than any other foreign & $-.791^{* *}$ & 0.648 \\
& destinations. & $-.802^{* *}$ & 0.640 \\
DP3 & I am more interested in visiting other destinations than Oman. & & \\
DP4 & I intend to visit other destination than Oman in the near future. & & \\
\hline
\end{tabular}

** Correlation is significant at the 0.01 level (2-tailed). 
Tests of validity and reliability for both scales were conducted using convergent validity and discriminant validity to verify validity of constructs and Cronbach's alpha to check reliability. As both loyalty and preference scales are unidimensional measures, there is no need found to conduct dimensionality test. The pilot test indicate on a satisfactory discrimination validity for both destination loyalty $(\mathrm{t}$-value $=-23.68$, $\mathrm{p}$-value $<0.001)$ and destination preference $(\mathrm{t}-\mathrm{value}=-$ 24.42, p-value $<0.001)$. Table 1 presents the Convergent validity and reliability tests for destination loyalty and preference scales. It is observed that destination loyalty and destination preference scales have satisfied convergent validity where all correlation coefficients are significant at 0.01 confidence level. Also, both of them have satisfied internal consistency where alpha coefficients are more than 0.7 for each scale.

\section{The results}

\section{Data Screening}

Among 300 questionnaires distributed to international tourists in Oman, 269 questionnaires were returned, which represent a response rate of $89.7 \%$. Among the 269 returned questionnaires, 239 questionnaires were finished entirely. However, this was not the valid sample size for overall measurement and structural model testing. It was found that in addition to double checks for the same items in some questionnaires, a group of items had all been doubtfully checked consecutively with the same point on the scale. As a result, 16 dubious cases had been eliminated. The remaining 223 cases were finally used as the validate dataset for the analysis.

After variables' coding and variable file preparing using SPSS program, all responses were entered. The first step of data screening was dealing with missing data. Missing value analysis was conducted and the results indicated some few missing data that had been handled. Outlier exclusion analysis was also conducted to identify extreme data. Only few cases were observed and handled. As per the importance of normality distribution in parametric analysis, data normality tests were used to determine whether a dataset is well-modeled by a normal distribution or not. Two methods are used to test the normality of data distribution: Kolmogrov-Smirnov (K-S) test, and Shapiro-Wilk (S-W) test. Results ensured the normality of data distribution for all constructs and items, where all K-S statistics and S-W statistics are significance at 95\% confidence interval for all items (table 2).

Table 2: Tests of Normality for Destination Loyalty and Destination Preference

\begin{tabular}{|c|c|c|c|c|c|}
\hline \multicolumn{2}{|r|}{ Construct / Item } & \multicolumn{2}{|c|}{ K-S Test } & \multicolumn{2}{|c|}{ S-W Test } \\
\hline & & Statistics & Sig. & Statistics & Sig. \\
\hline DL & DESTINATION LOYALTY & & & & \\
\hline DL1 & $\begin{array}{l}\text { I will recommend Oman to others (including my family } \\
\text { and friends). }\end{array}$ & 0.188 & 0.000 & 0.905 & 0.000 \\
\hline DL2 & I will say positive things about Oman to other people. & 0.240 & 0.000 & 0.888 & 0.000 \\
\hline DL3 & I will encourage other people to visit Oman. & 0.176 & 0.000 & 0.901 & 0.000 \\
\hline DL4 & $\begin{array}{l}\text { I will consider Oman again while travelling abroad for a } \\
\text { holiday. }\end{array}$ & 0.238 & 0.000 & 0.887 & 0.000 \\
\hline DL5 & I will visit Oman again within the next 2 Years. & 0.274 & 0.000 & 0.866 & 0.000 \\
\hline DL6 & I would like to stay longer in Oman if I could. & 0.222 & 0.000 & 0.881 & 0.000 \\
\hline DL7 & $\begin{array}{l}\text { There are many other attractions that I want to visit in } \\
\text { Oman. }\end{array}$ & 0.205 & 0.000 & 0.866 & 0.000 \\
\hline DL8 & I don't think that I spent enough time in Oman. & 0.205 & 0.000 & 0.888 & 0.000 \\
\hline DP & DESTINATION PREFERENCE & & & & \\
\hline DP1 & Oman is my first choice. & 0.221 & 0.000 & 0.901 & 0.000 \\
\hline DP2 & $\begin{array}{l}\text { Oman is more attractive to me than any other foreign } \\
\text { destinations. }\end{array}$ & 0.195 & 0.000 & 0.901 & 0.000 \\
\hline DP3 & $\begin{array}{l}\text { I am more interested in visiting other destinations than } \\
\text { Oman. }\end{array}$ & 0.186 & 0.000 & 0.909 & 0.000 \\
\hline DP4 & $\begin{array}{l}\text { I intend to visit other destination than Oman in the near } \\
\text { future. }\end{array}$ & 0.206 & 0.000 & 0.906 & 0.000 \\
\hline
\end{tabular}




\section{Respondents' Demographic Profile:}

The inbound tourist profile of 223 respondents is shown in Table 3. Respondents consist of more male tourists (72.6\%) than female tourists $(27.4 \%)$. The majority of the respondents are between the ages $41-50$, which accounts for $43.5 \%$ of the total respondents. The second largest group of respondents is those between 31-40 representing $21.5 \%$ of the total respondents. The age of the remaining respondents are distributed among the age group of 21-30 (16.6\%), 51-60 (12.6), and the least respondents in the upper (61 and above (3.1\%)) and lower (20 and under (2.7\%)) age groups.

Table 3: Demographic profile of respondents

\begin{tabular}{|c|c|c|c|c|c|}
\hline $\begin{array}{l}\text { Demographic } \\
\text { Variables }\end{array}$ & Frequency (n) & $\begin{array}{l}\text { Percent } \\
(\%)\end{array}$ & Demographic Variables & Frequency (n) & $\begin{array}{l}\text { Percent } \\
(\%)\end{array}$ \\
\hline Gender & & & Marriage & & \\
\hline Male & 162 & 72.6 & Single & 45 & 20.2 \\
\hline \multirow[t]{2}{*}{ Female } & 61 & 27.4 & Married & 175 & 78.5 \\
\hline & & & Other & 3 & 1.3 \\
\hline \multicolumn{6}{|l|}{ Age } \\
\hline 20 and Under & 6 & 2.7 & Education & & \\
\hline $21-30$ & 37 & 16.6 & High school or less & 22 & 9.9 \\
\hline $31-40$ & 47 & 21.5 & $\begin{array}{l}\text { Associate degree/ technical } \\
\text { certificate }\end{array}$ & 37 & 16.6 \\
\hline $41-50$ & 97 & 43.5 & Bachelor's Degree & 102 & 45.7 \\
\hline $51-60$ & 28 & 12.6 & Master's Degree & 50 & 22.4 \\
\hline 61 and Above & 7 & 3.1 & Ph.D/ Doctoral & 12 & 5.4 \\
\hline
\end{tabular}

Regarding the education level, most of the respondents hold the degree of bachelor (45.7\%) and master degree (22.4). Holders of associate degree/technical certificates account for $16.6 \%$ among the total respondents. Respondents with the lowest education level (high school or less) represent 9.9\%, and those with the highest $\mathrm{PhD/doctoral} \mathrm{represent} \mathrm{5.4 \%} \mathrm{of} \mathrm{the}$ total respondents.

\section{Tourists' perceptions Towards Destination Loyalty and Preference}

After an acceptable validity and reliability for destination loyalty and preference scales, the descriptive analysis was conducted to identify the characteristics of research variables, and capture the perceptions of inbound tourists toward Oman destination loyalty and preference. Table 4 indicates the results of descriptive analysis for all constructs under study. More than $83 \%$ of all respondents have high loyalty towards Omani tourism destination. Also, as observed from table 4, all attributes of destination loyalty are positively perceived by inbound tourists and the mean values of destination loyalty range from 5.44 to 5.70. In other words, all loyalty attributes have mean values higher than four $(4=$ neutral $)$ and all responses are "agree" or "totally agree". These findings are supported by significant chi-square for all attributes ranged from 45.77 to 107.56 (p.value < 0.01 ).

Table 4: Frequencies, Descriptive Analysis and Chi Square Test for Destination Loyalty and Preference $(n=223)$

\begin{tabular}{|c|c|c|c|c|c|c|c|c|c|c|c|}
\hline \multirow[b]{2}{*}{ Construct /Item } & \multicolumn{7}{|c|}{ Frequencies (\%) } & \multicolumn{2}{|c|}{ Descriptive Statistics } & \multicolumn{2}{|c|}{ Chi Square } \\
\hline & 1 & 2 & 3 & 4 & 5 & 6 & 7 & Mean & St. Dev & $\mathrm{X} 2$ & Sig. \\
\hline \multicolumn{12}{|l|}{ DL } \\
\hline DL1 & 0.0 & 0.0 & 4.5 & 16.1 & 30.0 & 30.0 & 19.3 & 5.44 & 1.11 & 51.06 & 0.000 \\
\hline DL2 & 0.0 & 0.0 & 5.8 & 11.2 & 26.0 & 39.0 & 17.9 & 5.52 & 1.09 & 75.81 & 0.000 \\
\hline DL3 & 0.0 & 0.0 & 4.9 & 15.2 & 30.0 & 27.4 & 22.4 & 5.47 & 1.14 & 45.77 & 0.000 \\
\hline DL4 & 0.0 & 0.0 & 5.4 & 10.3 & 29.1 & 39.9 & 15.2 & 5.49 & 1.04 & 90.34 & 0.000 \\
\hline DL5 & 0.0 & 0.0 & 6.7 & 9.9 & 23.8 & 45.3 & 14.3 & 5.51 & 1.07 & 107.56 & 0.000 \\
\hline DL6 & 0.0 & 0.0 & 6.7 & 11.2 & 23.3 & 33.2 & 25.6 & 5.60 & 1.18 & 52.31 & 0.000 \\
\hline DL7 & 0.0 & 0.0 & 5.4 & 4.0 & 31.4 & 34.1 & 25.1 & 5.70 & 1.06 & 91.73 & 0.000 \\
\hline DL8 & 0.0 & 0.0 & 6.3 & 11.2 & 26.5 & 31.4 & 24.7 & 5.57 & 1.16 & 51.15 & 0.000 \\
\hline \multicolumn{12}{|l|}{ DP } \\
\hline DP1 & 0.0 & 0.0 & 8.1 & 16.6 & 25.1 & 35.0 & 15.2 & 5.33 & 1.16 & 47.61 & 0.000 \\
\hline DP2 & 0.0 & 0.0 & 1.8 & 17.5 & 32.3 & 32.3 & 16.1 & 5.44 & 1.02 & 72.99 & 0.000 \\
\hline DP3 & 12.6 & 29.1 & 34.1 & 14.8 & 9.4 & 0.0 & 0.0 & 2.79 & 1.13 & 53.12 & 0.000 \\
\hline DP4 & 17.0 & 32.3 & 26.5 & 17.5 & 6.7 & 0.0 & 0.0 & 2.65 & 1.15 & 42.81 & 0.000 \\
\hline
\end{tabular}


Table 4 indicated also that around $80.67 \%$ of all respondents are saying positively about the destination and recommending Omani destination to others. $79.3 \%$ of all respondents recommend Oman to others (including families and friends). $82.9 \%$ of respondents say positive things about Oman to other people. $79.8 \%$ of respondents encourage other people to visit Oman. The mean values and chi square statistics ensured the same, where recommendation intentions get more than five as a mean value with significant chi square statistics ranged from 45.77 to 75.81 .

Revisit intentions get more interest from inbound tourist to Oman, where $84.58 \%$ of all respondents appeared their intentions to revisit Oman tourism destination. They agreed that they will: consider Oman again while travelling abroad for a holiday (84.2\%); visit Oman again within the next 2 Years (83.4\%); stay longer in Oman if they could (82.1\%); there are many other attractions that they want to visit in Oman (90.6); and they don't think that they spent enough time in Oman (82.6\%). The findings of revisit intentions are supported by significant chi-square for all attributes ranged from 51.15 to 107.56 (p.value < 0.001). Thus, the hypotheses H1a and H1b are supported as Omani tourism destination is highly recommended by inbound tourists to Oman and inbound tourists have high revisit intentions towards Oman tourism destination. As a result of the above findings, the first hypothesis (H1) is supported where inbound tourists have high loyalty to Omani tourism destination through high revisit intentions and recommendation intentions.

Regarding destination preference, $75.3 \%$ of all respondents agreed that Oman is their first choice and $80.7 \%$ agreed that Oman is more attractive to them than any other foreign destinations. The attributes with negative expressions ensured the same as $75.8 \%$ of all respondents are not interested in visiting other destinations than Oman and do not intend to visit other destination than Oman in the near future. The significant chi square statistics supported these finding where the $\chi^{2}$ values ranged from 42.81 to 72.99 with $p$-value lesser than 0.01 . These findings of destination preference support the second hypothesis as Oman tourism destination is highly preferred by inbound tourists.

\section{The Impact of destination Preference on Destination Loyalty}

To test the fifth hypothesis that proposed that destination preference has direct positive and significant effects on destination loyalty, a linear regression model was designed. This model assumed that destination preference as independent variable affects destination loyalty as dependent variable as shown in the following equation:

$$
\mathrm{DL}=\alpha+\beta \text { DP }
$$

Where DL is the dependent variable (destination loyalty), DP refers to the explanatory variable (destination preference). The slope of the line is $\beta$, and $\alpha$ is the intercept (the value of DL when DP $=0$ ). The first step with this model is testing the model fit. As indicated in table 5, the model has satisfied model fit and there is linear relationship between destination loyalty as dependent variable and destination preference as independent variable $(\mathrm{F}=30.78$, $\mathrm{p}$-value $<0.01)$.

Table 5: Results of regression Analysis (ANOVA) $(n=223)$

\begin{tabular}{|l|r|r|r|r|r|}
\hline Model & \multicolumn{1}{|c|}{$\begin{array}{c}\text { Sum of } \\
\text { Squares }\end{array}$} & df & Mean Square & \multicolumn{1}{c|}{ F } & \multicolumn{1}{c|}{ Sig. } \\
\hline Regression & 889.363 & 1 & 889.363 & 30.777 & .000 \\
Residual & 6386.269 & 221 & 28.897 & & \\
\cline { 1 - 3 } Total & 7275.632 & 222 & & & \\
\hline
\end{tabular}

Independent Variable: Destination Preference

Dependent Variable: Destination Loyalty

The results of the analysis of variance show the values of the slope and the intercept as shown in the following equation:

$$
\mathrm{DL}=31.45+0.35 \mathrm{DP}
$$

The explanatory variable (destination preference) has a positive and significant influence on the dependent variable (destination loyalty) $(\beta=0.350, T=5.548, p$-value $=0.000)$. The results of correlation analysis ensured the significant relationship between destination loyalty and destination preference $(\mathrm{R}=0.350$, $\mathrm{p}$-value $<0.01)$. The value of adjusted $\mathrm{R} 2$ indicated that $11.8 \%$ of changes in destination loyalty occurred as a result of changes in destination preference with one standard deviation. Therefore, the third hypothesis is supported as destination preference has direct positive and significant effects on destination loyalty. 


\section{The Influence of Tourist's Demographic Characteristics on Destination Loyalty and Preference}

Gender, age, marital status and education are the personal characteristics which have been selected and examined in this section. Independent Samples T-Test and ANOVA analysis were used to examine the influence of these personal characteristics on both destination loyalty and preference. Independent Samples T-Test was used to examine the influence of gender and marital status; and ANOVA was used to examine the influence of age and educational level. The findings of Independent Samples T-Test are presented in table 6. As could be observed from table 6, there is no significant differences between the perceptions of male and female towards both destination loyalty $(T=-0.276$, $p$-value $=0.783$ ) and destination preference $(T=0.282$, $p$-value $=0.568)$. Also, no significant differences exist between single and married tourist perceptions towards destination loyalty $(\mathrm{T}=0.282, \mathrm{p}$-value $=0.779)$ and preference $(\mathrm{T}=-0.234$, $\mathrm{p}$-value $=0.816)$. Therefore, neither gender nor marital status has significant influence on tourists' loyalty or preference.

Table 6: The Results of Independent-Samples T-Test $(n=223)$

\begin{tabular}{|c|c|c|c|c|c|c|c|c|c|}
\hline & \multirow{2}{*}{ Variable } & \multirow{2}{*}{ Gender } & \multicolumn{3}{|c|}{ Group Statistics } & \multicolumn{4}{|c|}{ T-Test for Equality of Means } \\
\hline & & & $\mathbf{N}$ & Mean & $\begin{array}{c}\text { Std. } \\
\text { Deviation }\end{array}$ & $\begin{array}{c}\text { Mean } \\
\text { Difference }\end{array}$ & $\mathbf{T}$ & df & $\begin{array}{l}\text { Sig. (2- } \\
\text { tailed) }\end{array}$ \\
\hline \multirow[t]{4}{*}{$\overline{\text { GENDER }}$} & \multirow{2}{*}{$\begin{array}{l}\text { Destination } \\
\text { Loyalty }\end{array}$} & Male & 162 & 44.22 & 5.399 & \multirow[t]{2}{*}{-0.25} & \multirow[t]{2}{*}{-0.276} & \multirow[t]{2}{*}{92.31} & \multirow[t]{2}{*}{0.783} \\
\hline & & Female & 61 & 44.47 & 6.556 & & & & \\
\hline & \multirow{2}{*}{$\begin{array}{l}\text { Destination } \\
\text { Preference }\end{array}$} & Male & 162 & 16.25 & 1.953 & \multirow[t]{2}{*}{0.17} & \multirow[t]{2}{*}{0.573} & \multirow[t]{2}{*}{221} & \multirow[t]{2}{*}{0.568} \\
\hline & & Female & 61 & 16.08 & 1.819 & & & & \\
\hline \multirow{4}{*}{$\begin{array}{l}\text { MARITAL } \\
\text { STATUS }\end{array}$} & \multirow{2}{*}{$\begin{array}{l}\text { Destination } \\
\text { Loyalty }\end{array}$} & Single & 45 & 44.51 & 6.051 & \multirow[t]{2}{*}{.28} & \multirow[t]{2}{*}{.282} & \multirow[t]{2}{*}{64.793} & \multirow[t]{2}{*}{.779} \\
\hline & & Married & 178 & 44.23 & 5.656 & & & & \\
\hline & \multirow{2}{*}{$\begin{array}{l}\text { Destination } \\
\text { Preference }\end{array}$} & Single & 45 & 16.13 & 2.282 & \multirow[t]{2}{*}{-.085} & \multirow[t]{2}{*}{-.234} & \multirow[t]{2}{*}{58.857} & \multirow[t]{2}{*}{.816} \\
\hline & & Married & 178 & 16.22 & 1.817 & & & & \\
\hline
\end{tabular}

As could be perceived from the findings of ANOVA analysis presented in table 7, age has no significant effects on destination loyalty $(\mathrm{F}=1.26, \mathrm{p}>0.05)$ or destination preference $(\mathrm{F}=1.39, \mathrm{p}>0.05)$. The same findings for education, whereas there is no evidence to support the impacts of it on loyalty $(\mathrm{F}=1.74, \mathrm{p}>0.05)$ and preference as well $(\mathrm{F}=1.09, \mathrm{p}>0.05)$. Therefore, neither age nor education has significant influence on destination loyalty or destination preference. Thus, the last hypothesis is supported where demographic characteristics (gender, age, marital status and education) have no significant influence on tourists' loyalty and preference.

Table 7: The Results of ANOVA Analysis ( $\mathrm{n}=223)$

\begin{tabular}{|c|c|c|c|c|c|c|c|}
\hline & & & $\begin{array}{c}\text { Sum of } \\
\text { Squares }\end{array}$ & df & $\begin{array}{c}\text { Mean } \\
\text { Square }\end{array}$ & $\mathbf{F}$ & Sig. \\
\hline \multirow[t]{6}{*}{ AGE } & Destination Loyalty & Between Groups & 205.355 & 5 & 41.071 & 1.261 & .282 \\
\hline & & Within Groups & 7070.277 & 217 & 32.582 & & \\
\hline & & Total & 7275.632 & 222 & & & \\
\hline & Destination & Between Groups & 34.581 & 5 & 6.916 & 1.926 & .091 \\
\hline & & Within Groups & 779.338 & 217 & 3.591 & & \\
\hline & & Total & 813.919 & 222 & & & \\
\hline \multirow[t]{6}{*}{ EDUCATION } & Destination Loyalty & Between Groups & 224.635 & 4 & 56.159 & 1.736 & .143 \\
\hline & & Within Groups & 7050.997 & 218 & 32.344 & & \\
\hline & & Total & 7275.632 & 222 & & & \\
\hline & $\begin{array}{l}\text { Destination } \\
\text { Preference }\end{array}$ & Between Groups & 15.908 & 4 & 3.977 & 1.086 & .364 \\
\hline & & Within Groups & 798.011 & 218 & 3.661 & & \\
\hline & & Total & 813.919 & 222 & & & \\
\hline
\end{tabular}




\section{Descussion, conclusion and future research}

The purpose of this study was to explore the inbound tourists' perceptions towards Oman destination loyalty and preference. Also, it aimed to investigate the impact of destination preference on destination loyalty. Moreover, the influence of tourists' demographic characteristics on both destination loyalty and preference was examined. A survey was conducted through 300 self-administrated questionnaires distributed to inbound tourists in Oman. The findings revealed that inbound tourists have high loyalty to the Omani tourism destination either by recommending it to others or intending to revisit it again.

The present study assessed the relationship between destination preference and loyalty and found that there is a linear relationship between them. Destination preference is the antecedent of destination loyalty and has a positive and

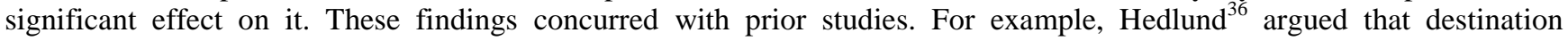
preference was seen as direct antecedent of destination choice that in turn influence the attitude of tourists toward a place, which often led to repeated patronage and word-of-mouth intentions. Also, the findings of this study concluded that demographic characteristics of inbound tourist to Oman have no significant influence over their perceptions towards destination loyalty and preference. The demographic characteristics involved in this study were gender, age, marital status and education. The findings from some studies in tourism literature are parallel with these findings. For example, Lepsito and McCleary's empirical study concluded that age did not affect customer preference for a particular type of hotel for pleasure travel. ${ }^{43}$ Examination of park preferences revealed that older adults were more likely to prefer recreation to conservation than younger adults. ${ }^{44}$ Also, Dimitriades ${ }^{45}$ found no significant relationship between age and loyalty in tourism services. Recently, the findings of $\mathrm{Chi}^{3}$ revealed that travelers in different age segments exhibited no significant difference in their perception of the destination loyalty. Furthermore, Crawford-Welch ${ }^{50}$ observed that female and male business travelers had similar consumption patterns. The findings of $\mathrm{Chi}^{3}$ shared the same and found comparable levels of loyalty and preference across males and females. She also showed no influence for education on loyalty and preference.

This study contributes theoretically to the tourism literature in several important ways. The first theoretical contribution of this study is recovering the limited investigation pertained in the tourism literature concerned with the relationship between destination preference and loyalty. It takes a turn for the better understanding of that relationship. Also, this study contributes to the current knowledge by filling a gap in the tourism literature regarding the effects of tourists' demographics on destination loyalty and preference especially for Arab world countries like Oman.

With respect to practical contributions, the findings may help destination marketers and operators in developing a better understanding of the nature and level of loyalty and preference towards Oman tourism destination. In addition, developing and implementing an effective and efficient marketing strategy that centers on loyalty requires a clear understanding of the critical importance of the relationship between individuals buying preferences and their product loyalty. Thus, this study provides empirical evidence for the linear relationship between tourist preference and loyalty. Furthermore, the findings may potentially assist managers in the development of promotional and loyalty programs for Oman tourism destination.

To keep a loyal tourist or convert a regular customer to a loyal one, it is recommended that destination marketers and operators as well as tourism providers have to exceed tourists expectation by providing unique experiences, committing to customers, treating them as unique individuals, valuing their opinions and feedbacks, and making their life easy by minimizing the effort required to deal with issues related to products before, during and after the trip or purchase. Also, further research is suggested for investigating other factors that may influence tourists' loyalty toward Oman tourism destination. 


\section{References}

${ }^{1}$ Pritchard, M., \& Howard, D. R. (1997). The loyal traveler: Examining a typology of service patronage. Journal of Travel Research, 35 (4), 2-10.

${ }^{2}$ Lee, J., Graefe, A. R., \& Burns, R. C. (2007). Examining the antecedents of destination loyalty in a forest setting. Leisure Sciences, 29 (5), 463-481.

${ }^{3}$ Chi, C. G-Q. (2011). Destination loyalty formation and travelers' demographic characteristics: A multiple group analysis approach. Journal of Hospitality \& Tourism Research, 35(2), 191-212.

${ }^{4}$ Sun, A., Chi, C. G., \& Xu, H. (2013). Developing destination Loyalty: The case of Hainan Island, China. Annals of Tourism Research, 43, 547-577.

${ }^{5}$ Oliver, R. L. (1999). Whence consumer loyalty? Journal of Marketing, 63, 33-44.

${ }^{6}$ Chen, J., \& Gursoy, D. (2001). An investigation of tourists' destination loyalty and preferences. International Journal of Contemporary Hospitality Management, 13, 79-86.

${ }^{7}$ Oppermann, M. (2000). Tourism destination loyalty. Travel Research, 39(1), 78-84.

${ }^{8}$ Alegre, J., \& Juaneda, C. (2006). Destination loyalty: Consumers' economic behavior. Annals of Tourism Research, 33, 684-706.

${ }^{9}$ Smit, E., Bronner, F., \& Tolboom, M. (2007). Brand relationship quality and its value for personal contact. Journal of Business Research, 60, 627-633.

${ }^{10}$ Reichheld, F., \& Sasser, W. (1990). Zero defects: Quality comes to services. Harvard Business Review, 105-111.

${ }^{11}$ Schiffman, L. G., \& Kanuk, L. L. (2007). Consumer behavior ( $9^{\text {th }}$ ed.). New Jersey: Pearson Prentice Hall.

${ }^{12}$ O’Brien, L., \& Jones, C. (1995). Do rewards really create loyalty? Harvard Business Review May/June, 75-82.

${ }^{13}$ Reichheld, F., \& Teal, T. (1996). The loyalty effect: The hidden force behind growth, profits and lasting value. Boston, MA: Harvard Business School Press.

${ }^{14}$ Weiner, B. (2000). Attributional thoughts about consumer behavior. Journal of Consumer Research, 27, 382-387.

15 Snyder, D. R. (1991). Demographics correlates to loyalty in frequently purchased consumer services. Journal of Professional Services Marketing, 8, 45-55.

${ }^{16}$ Exter, T. (1986). Looking for brand loyalty. American Demographics, April, 33-50.

${ }^{17}$ Hsu, C. H. (2000). Determinants of mature travels' motor-coach tour satisfaction and brand loyalty. Journal of Hospitality \& Tourism Research, 24, 223-238.

${ }^{18}$ Mykletun, R. J., Crotts, J. C., \& Mykletun, A. (2001). Positioning an island destination in the peripheral area of the Baltics: A flexible approach to market segmentation. Tourism Management, 22, 493-500.

${ }^{19}$ Day, G. S. (1969). A two-dimensional concept of brand loyalty. Journal of Advertising Research, 9 (3), 29-35.

${ }^{20}$ Jacoby, J., \& Chestnut, R. W. (1978). Brand loyalty: Measurement and management. New York: John Wiley.

${ }^{21}$ Selin, S. W., Howard, D. R., Udd, E., \& Cable, T. (1988). An analysis of consumer loyalty to municipial recreation programs. Leisure Sciences, 10, 210-223.

${ }^{22}$ Zeithaml, V. A., Berry, L. L., \& Parasuraman, A. (1996). The behavioural consequences of service quality. Journal of Marketing, 60, 31-46.

${ }^{23}$ Yoon, Y., \& Uysal, M. (2005). An examination of the effects of motivation and satisfaction on destination loyalty: A structural model. Tourism Management, 26, 45-56.

${ }^{24}$ Pritchard, M. P., Howard, D. R., \& Havitz, M. E. (1992). Loyalty measurement: a critical examination and theoretical extension. Leisure Sciences, 14 (2), 155-164.

${ }^{25}$ Oppermann, M. (1999). Predicting destination choice: A discussion of destination loyalty. Vacation Marketing 5(1), 5165. 
${ }^{26}$ Jago, L. K., \& Shaw, R. N. (1998). Special events: A conceptual and definitional framework. Festival Management and Event Tourism 5(1), 21-32.

${ }^{27}$ Jones, T. O., \& Sasser, E. W. (1995). Why satisfied customers defect. Harvard Business Review, November/December, 88-99.

${ }^{28}$ Schall, M. (2003). Best practices in the assessment hotel-guest attitude. Cornell Hotel and Restaurant Administration Quarterly, 44(2), 51-66.

${ }^{29}$ Velázquez, B. M., Saura, I. G., \& Molina, M. E. R. (2011). Conceptualizing and measuring loyalty: Towards a conceptual model of tourist loyalty antecedents. Journal of Vacation Marketing, 17(1), 65-81.

${ }^{30}$ Backman, S. J. (1988). The utility of selected personal and marketing characteristics in explaining consumer loyalty to selected recreation services. Unpublished doctoral thesis, Texas A\&M University.

${ }^{31}$ Baloglu, S. (2001). An investigation of a loyalty typology and the multidestination loyalty of international travellers. Tourism Analysis, 6, 41-52.

${ }^{32}$ Oppermann, M. (1998). Destination threshold potential and the law of repeat visitation. Journal of Travel Research, 37 (2), 131-137.

${ }^{33}$ Petrick, J. F. (2005). Reoperationalising the loyalty framework. Tourism and Hospitality Research, 5(3), 199-212.

${ }^{34}$ Rundle-Thiele, S. (2005). Exploring loyal qualities: Assessing survey-based loyalty measures. Journal of Services Marketing, 19(7), 492-500.

${ }^{35}$ Backman, S. J., \& Crompton, J. L. (1991). Differentiating between high, spurious, latent, and low loyalty participants in two leisure activities. Journal of Park and Recreation Administration, 9 (2), 1-17.

${ }^{36}$ Hedlund, T. (2013). Tourists' vacation choice structure: Influence of values and implications for green tourism. Studies in Business Administration, Series B, No. 83, Print \& Media, Umeå University, Sweden.

${ }^{37}$ Decrop, A. (2006). Vacation decision-making. Wallingford: CABI Publishing.

${ }^{38}$ Svenson, O. (1979). Process descriptions of decision making. Organizational Behavior and Human Performance, 23, 89112.

${ }^{39}$ Woodside, A. G., \& MacDonald, R. (1994). General system framework of customer choice processes of tourism services. In R. V. Gasser, \& K. Weiermair (Eds.), Spoilt for choice-Decision making processes and preference changes of tourists: Intertemporal and intercountry perspectives (pp. 30-59). Thaur-Wien-München: Kulturverlag.

${ }^{40}$ Swarbrooke, J., \& Horner, S. (2007). Consumer behaviour in tourism ( $2^{\text {nd }}$ ed.). Oxford: Elsevier.

${ }^{41}$ Teare, R. (1994). Consumer decision making. In R. Teare, J. A. Mazanec, S. Crawford-Welch, \& S. Calver (Eds.), Marketing in hospitality and tourism: A consumer focus (pp. 1-96). London: Cassell.

${ }^{42}$ Decrop, A., \& Snelders, D. (2004). Planning the summer vacation: An adaptable process. Annals of Tourism Research, 31(4), 1008-1030.

${ }^{43}$ Lepsito, L. R., \& McCleary, K. W. (1988). The effect of multiple measures of age in segmenting hotel markets. The Council on Hotel, Restaurant, and Institutional Education, August, 91-99.

${ }^{44}$ Payne, L. L., Mowen, A. J., \& Orsega-Smith, E. (2002). An examination of park preferences and behaviors among urban residents: The role of residential location, race, and age. Leisure Sciences, 24,181-198.

45 Dimitriades, Z. S. (2006). Customer satisfaction, loyalty and commitment in service organizations. Management Research News 29(12), 782-800.

${ }^{46}$ Moisey, R. N., \& Bichis, M. (1999). Psychographics of senior nature tourists: Nature trail. Tourism Recreation Research, $24,69-76$.

${ }^{47}$ Wood, L. M. (2004). Dimensions of brand purchasing behavior: Consumers in the 18-24 age group. Journal of Consumer Behavior, 4(1), 9-24.

${ }^{48}$ Patterson, P. G. (2007). Demographic correlates of loyalty in a service context. Journal of Services Marketing, 21(2), 112-121. 
${ }^{49}$ Hossain, M. E. (2012). Moderating roles of visitors' demographic in the destination loyalty process within the context of cox's bazar, bangladesh. $3^{\text {rd }}$ International Conference on Business and Economic Research ( ${ }^{\text {rd }}$ ICBER 2012) proceeding (March 12-13), 2168-2185.

${ }^{50}$ Crawford-Welch, S. (1988). The female business customer: An analysis of provisions and consumption patterns in the U.S. lodging industries. Hospitality Education and Research Journal, 12, 475-493.

${ }^{51}$ McCleary, K. W., Weaver, P. A., \& Lan, L. (1994). Gender-based differences in business travelers' lodging preferences. Cornell H.R.A. Quarterly, April, 51-58.

${ }^{52}$ Meng, F., \& Uysal, M. (2008). Effects of gender differences on perceptions of destination attributes, motivations, and travel values: An examination of a nature-based resort destination. Journal of Sustainable Tourism, 16, 445-465.

${ }^{53}$ McColl-Kennedy, J., Daus, C., \& Sparks, B. (2003). The role of gender in reactions to service failure and recovery. Journal of Service Research 6(1), 66-82.

${ }^{54}$ Mechinda, P., Serirat, S., \& Gulid, N. (2009). An examination of tourists' attitudinal and behavioral loyalty: Comparison between domestic and international tourists. Journal of Vacation Marketing 15(2), 129-148.

${ }^{55}$ Hellier, P. K., Geursen, G. M., Carr, R. A., \& Ritchard, J. A. (2003). Customer repurchase intention: A general structural equation model. European Journal of Marketing, 37(11/12), 1762-1800.

ولاء وتفضيلات السائحين للمقصد السياحي العُماني: دراسة تأثيرات الخصائص الديموجرافية للسائحين

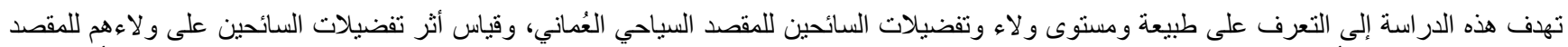

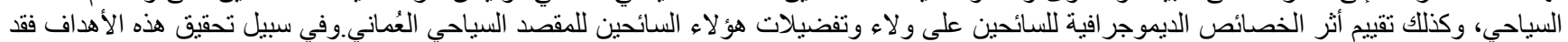

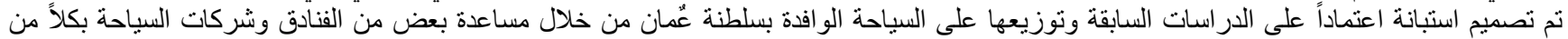

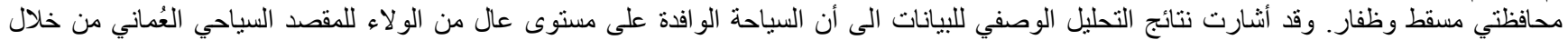

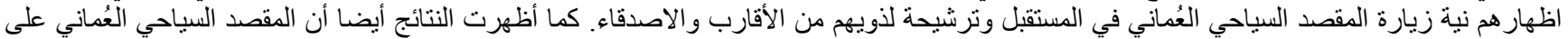

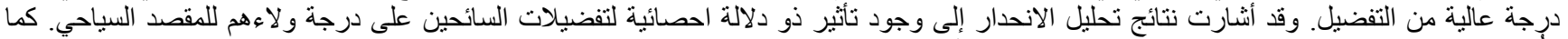

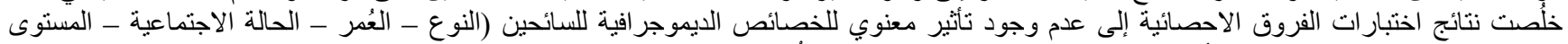

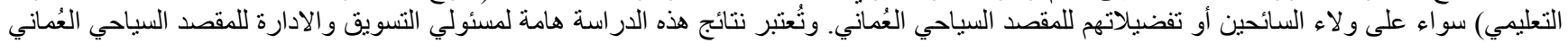

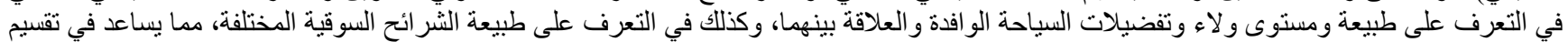

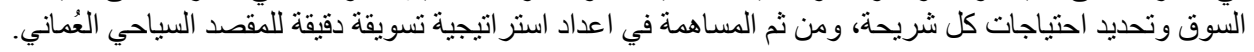
الكلمات الاالة: السباحة، تفضيلات السائحين، و لاء السائحين، الخصائص الديموجر افية، سلطنة عُمان الدان 